\title{
Spatial linkages between settling young-of-year and older juvenile lobsters
}

\author{
Victoria H. M. Burdett-Coutts ${ }^{1, *}$, Richard A. Wahle ${ }^{2}$, Paul V. R. Snelgrove ${ }^{1}$, \\ Rémy Rochette ${ }^{3}$
}

${ }^{1}$ Biology Department and Ocean Sciences Centre, Memorial University of Newfoundland, St. John's, Newfoundland A1C 5S7, Canada

${ }^{2}$ School of Marine Sciences, University of Maine, Darling Marine Center, Walpole, Maine 04573, USA

${ }^{3}$ Biology Department, University of New Brunswick, Saint John, New Brunswick E2L 4L5, Canada

\begin{abstract}
We examined spatial association between young-of-year (YoY) and older juvenile (Juv) American lobsters Homarus americanus across multiple spatial scales using 8 years (2001 to 2008) of field measurements of a long-term settlement index time series from New England, USA. Complementary laboratory experiments examined behavioural responses of settling postlarvae to conspecific presence. Regional scale (10s to 100s of kilometres) data aggregation showed significant association between YoY recruitment and Juv densities in the same year for all 8 years examined. These broad-scale positive associations support previous research showing the importance of circulation-driven patterns of larval supply in linking newly settled YoY and Juv lobsters. Analysis at the quadrat scale, however, showed greater than expected association between YoY and Juv, suggesting a behavioural component. Early benthic-phase Juv lobsters ( 0 to 2 yr old) strongly associate with structurally complex habitats; however, little is known of other habitat quality variables that may enhance successful recruitment. Resident conspecifics may represent one of several habitat quality proxies for postlarval lobsters despite post-settlement risk in settling among conspecifics, such as competition and predation. In short-term (4 min) laboratory behavioural experiments, postlarvae spent significantly more time on the bottom in the presence of conspecific juveniles. In longer-term $(24 \mathrm{~h})$ experiments, postlarvae initially $(<1 \mathrm{~h})$, though not significantly, settled more rapidly in the presence of conspecific juveniles, and any weak effect dissipated with time. Lack of suitable habitat in experimental chambers may have inhibited a longer-term response. While conspecifics may initially attract postlarvae, settlement may require additional habitat cues.
\end{abstract}

KEY WORDS: Lobster - Postlarvae - Bottom-searching behaviour - Conspecific cues · Behaviour · Scaling $\cdot$ Recruitment

\section{INTRODUCTION}

Larval settlement of many marine benthic invertebrates marks the critical transition from a pelagic to a benthic habitat, as well as a dramatic shift in the scale of dispersal (Connell 1961, Paine \& Levin 1981). Spatial patterns of recruitment to benthic habitats are determined by the interaction of biological and physical processes that operate over a broad spectrum of spatial scales (Scheltema 1986, Roughgarden et al. 1988, Etherington \& Eggleston 2000, Pineda et al. 2009). Because interpretation of patterns and processes evident at one scale may change when viewed from another (Butman 1987), a comprehensive evaluation of recruitment mechanisms requires integration across multiple spatial scales (Hewitt et al. 1997, Thrush et al. 1997).

Benthic recruitment is typically defined as survival to a post-settlement stage (Connell 1985, Menge 1992). Processes that operate both before and after settlement influence survival to that point (Caley et al. 1996) because mortality at settlement and during 
the discrete stages that follow may ultimately define recruitment success. Pre-settlement processes operate for the duration of the planktonic stage and result from a combination of larval supply, transport, mortality, availability of suitable habitat, and behaviour (Butman 1987, Pineda 2000). Post-settlement processes can operate for the duration of benthic life and encompass a variety of physical and biological factors (Keough \& Downes 1982, Wahle \& Incze 1997).

Passive larval transport by ocean currents can influence dispersal and recruitment dynamics at multiple spatial scales, from ocean basins to grains of sand (Scheltema 1986, Snelgrove et al. 1993; see Pineda 2000, Pineda et al. 2009 for reviews). Although larval vertical movements in the water column can significantly influence the extent of passive horizontal transport (Kimmerer \& McKinnon 1987, Metaxas 2001, Vikebø et al. 2005), larval behaviour is typically believed to influence distribution patterns over smaller spatial scales (Butman 1987). For example, habitat selection at fine scales can influence patterns related to shelter and substrate quality (Seed \& Wood 1994, Hunt \& Scheibling 1997). Indeed, some species demonstrate a clear ability to discriminate between different habitats during larval or postlarval settlement (Butman et al. 1988, Krug \& Zimmer 2004).

The American lobster Homarus americanus is one of the most important commercial species on the east coast of North America. This species exhibits a complex life history typical of most marine decapods. Release of larvae over a 3 mo period starts in May toward its southern geographic limit and extends as late as August at its northern limit (Aiken \& Waddy 1980). Larvae develop through 3 larval stages and a postlarval stage, the last of which settles to the seafloor (Lawton \& Lavalli 1995). Unlike the larvae, postlarval lobsters are relatively strong swimmers and actively seek pre-existing shelter, resulting in strong association between juvenile stages and structurally complex habitats, such as cobbles and boulders (Scarratt 1973, Cooper \& Uzmann 1980, Wahle \& Steneck 1992). This association extends through their first year or two of life, likely in response to the threat of predation (Wahle \& Incze 1997), distinguishing them behaviourally and ecologically from larger, less vulnerable lobsters. Juvenile lobsters of the genus Homarus commonly use structurally complex habitats as refuge because these habitats provide survival advantages that include protection from predation, adverse hydrographic conditions, and other physiological stressors (Howard \& Nunny 1983, Lavalli \& Barshaw 1986, Wahle \& Steneck 1991).
To the extent that consistent annual differences in larval supply influence overall settlement patterns, and noting limited early juvenile movement, the density of recent settlers is expected to correlate spatially with that of older conspecifics $<3 \mathrm{yr}$ old. Given the dependence on cobble-boulder habitat for the first few years of life, settlement strength is a major determinant of older juvenile abundance in cobble nurseries (Wahle et al. 2004, 2013). Although juveniles outgrow this habitat dependence and emerge from nurseries after several years, the degree to which resident conspecifics promote or deter settlement of new cohorts remains unknown.

Larval behaviour at the time of settlement can optimize survival probability (Keough \& Downes 1982, Zimmer \& Butman 2000, Kingsford et al. 2002), where larvae utilize settlement cues including odour, substrate type and complexity, as well as conspecific presence (Pawlik 1992, O'Connor \& Richardson 1998, Head et al. 2004, Dworjanyn \& Pirozzi 2008). The larvae of many benthic taxa are attracted to conspecifics at settlement, including echinoderms (Burke 1986, Pearce \& Scheibling 1990), polychaetes (Jensen \& Morse 1984, Pawlik et al. 1991), molluscs (Tamburri et al. 2007), barnacles (Raimondi 1991), and ascidians (Young 1988). Positive responses to conspecifics can result in large mono-specific aggregations (reviewed by Burke 1986), though few studies have addressed aggregation during early recruitment in mobile marine species (but see Jensen 1989 for crabs). Pelagic postlarval lobsters can orient swimming toward adult odour (Boudreau et al. 1993), but conspecific attraction in American lobster has otherwise received little attention. Generally, clawed lobsters are asocial and do not share shelters (Childress \& Herrnkind 2001). However, settling postlarval lobster could benefit from the use of cues from conspecifics to guide them to favourable habitat. In contrast, settlement among conspecifics could negatively impact new recruit survival by enhancing intra-specific competition or cannibalism (Pechenik 1999, Moksnes 2004).

The American lobster settlement index is a longterm time series of young-of-year (YoY) lobster recruitment to coastal nurseries. The index has been collected over a broad spatial scale in New England, USA, and provides a powerful resource to evaluate settlement patterns and suggest mechanisms that may influence recruitment dynamics in this species (e.g. Wahle et al. 2013). In a related study, we showed a strong correlation between lobster settlement and the occurrence of older juveniles in collectors and suction samples over scales of 1 to $10 \mathrm{~km}$ (Wahle et al. 2013). Here, we expand on that work to 
identify the underlying mechanisms and relevant spatial scales driving that correlation. Specifically, we address whether YoY density depends on the resident population of older conspecifics by utilizing a multi-pronged approach in which we (1) evaluate the relationship between YoY and older juvenile (Juv) lobsters using 8 years (2001 to 2008) of the American lobster settlement index time series, analyzed at 3 spatial scales of data aggregation, and (2) present laboratory experiments that investigate behavioural responses of postlarval lobsters to the presence of older juvenile conspecifics.

\section{MATERIALS AND METHODS}

\section{Field settlement time series}

To evaluate the relationship between YoY and Juv density, we used data from the American lobster settlement index, a long-term, diver-based survey of lobster recruitment conducted in New England and Atlantic Canada (Fig. 1). SCUBA-based suction sampling surveys, conducted annually since 1989 in cobble-boulder nursery habitat $<10 \mathrm{~m}$ below mean low water at the end of the settlement season, span from late August in the southern regions to late October in the north (Incze \& Wahle 1991, Wahle \& Incze 1997). Although, strictly speaking, these data measure recruitment rather than settlement, the difference between recruitment and cumulative settlement has been shown to be negligible in the American lobster because post-settlement mortality rates are relatively low in areas of suitable habitat (Wahle \& Incze 1997, Palma et al. 1998). Sampling sites were arranged in a nested design, in which 12 to 18 quadrats were sampled within 3 to 15 sites within 11 regions. Quadrat samples were separated by a few metres, whereas sites were separated by 1 to $10 \mathrm{~km}$ and regions by $>100 \mathrm{~km}$. Sampling times at each location were sufficiently late in the season to ensure no significant additional settlement was likely. While we returned to

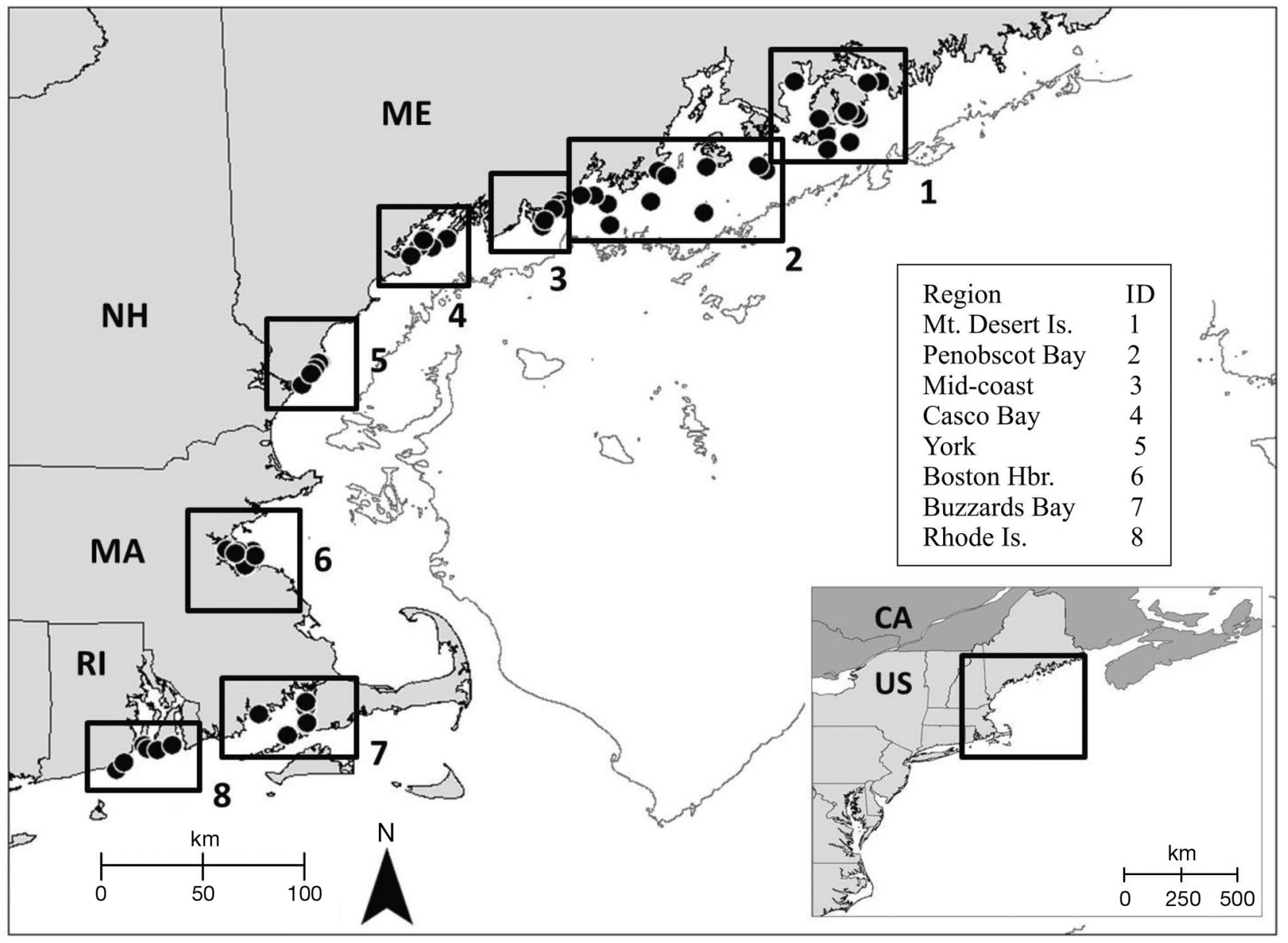

Fig. 1. American Lobster Settlement Index sites (circles) and regions (boxes) sampled from 2001 to 2008 in New England. Grey line denotes $100 \mathrm{~m}$ isobath 
and re-sampled the same regions and sites in consecutive years, specific quadrat locations varied and were spatially independent. Divers selected quadrat locations $\left(0.5 \mathrm{~m}^{2}\right.$ area) with a minimum of $50 \%$ cobble-boulder cover. All lobsters enumerated in quadrats were measured (carapace length to the nearest $0.1 \mathrm{~mm}$ ). The settlement index represents the density of YoY lobsters in the population at the time samples were collected (Wahle et al. 2004). Whereas precise aging of lobsters is an area of ongoing research (Wahle et al. 1996, Sheehy et al. 1999), longterm sampling in each study region has shown that YoY are distinguishable as a well-established mode in the size-frequency distribution (Incze \& Wahle 1991, Incze et al. 1997, Wahle et al. 2001, 2004). Based on these size parameters, we defined lobsters as either YoY or Juv (Table 1).

\section{Analysis}

We investigated the relationship between YoY and Juv density (individuals per $0.5 \mathrm{~m}^{2}$ ) at 3 spatial scales (region, site, quadrat) over an 8 yr segment of the $20 \mathrm{yr}$ time series (2001 to 2008). Although sampling began as early as 1989 in some regions, it started as late as 2001 in others; we therefore used a time block common to all regions. We excluded any regions not sampled every year and also excluded those regions where we sampled $<3$ sites in any of the 8 years. Prior to analysis, we square-root transformed raw count data per quadrat to normalize the data and stabilize the variance.

As an initial assessment of the relative importance of conspecific effects on YoY recruitment in the context of spatial and temporal variability, we used a GLM nested mixed-model ANCOVA in which we nested Site within Region (both random effects) and treated Year as a fixed-effect factor with 8 levels (2001 to 2008). Juv was a covariate in the analysis. We treated Region and Site, the latter hereafter denoted Site [Region], as random effects because they represent a small, random subset of possible regions and sites we could have considered and because we wanted to generalize our results to the relevant spatial scales rather than to specific sites and areas. Year was treated as a fixed effect because it included all years within the time frame of interest. We conducted a variance component analysis (VCA) to determine the proportion of variance associated with the 3 different spatial scales (Region, Site [Region], Quadrat). Secondly, we used regression analyses to evaluate the YoY to Juv relationship at 2 spatial scales: (1) data aggregated by region and (2) a separate analysis for each region with site as the sample unit. We used a Type II regression for these comparisons because both the dependent and independent variables were measured with error.

To evaluate the association between YoY and Juv at the quadrat scale, we devised an index of association (IA), which reflects the degree to which YoY associate with Juv (i.e. found in the same quadrat) within each site, relative to the expected behaviour if they settled independently of juveniles. We reasoned that this index provides a useful indication of postlarval choice, rather than larval supply, because variability in larval supply is unlikely to match variability in juvenile abundance at the quadrat scale and particularly unlikely to do so consistently across years and sites. Variability in larval supply is therefore unlikely to match juvenile distribution at the quadrat scale without behavioural contributions. For each site, we first reasoned that if YoY settlement was independent of Juv presence, we would expect that quadrats with and without juveniles would have the same probability of harbouring YoY. We calculated the difference between the observed and expected percentage of YoY associated with Juv (observed-expected) as the IA for that site, where the expected percentage was simply the percentage of quadrats that contained at least 1 juvenile. The number of quadrats sampled that actually contain juveniles constrains our theoretical minimum and maximum. While this

\begin{tabular}{lllrrrrrrrr}
\hline Mt. Desert Is. & $\leq 13$ & $>13$ & 3 & 4 & 5 & 5 & 5 & 5 & 5 & 5 \\
Penobscot Bay & $\leq 13$ & $>13$ & 9 & 9 & 8 & 9 & 11 & 11 & 11 & 11 \\
Mid-coast & $\leq 10.5$ & $>10.5$ & 10 & 10 & 10 & 10 & 10 & 10 & 10 & 10 \\
Casco Bay & $\leq 10.5$ & $>10.5$ & 5 & 5 & 5 & 5 & 5 & 5 & 5 & 5 \\
York & $\leq 10.5$ & $>10.5$ & 5 & 5 & 5 & 5 & 5 & 5 & 5 & 5 \\
Boston Hbr. & $\leq 12$ & $>12$ & 7 & 7 & 7 & 6 & 7 & 7 & 7 & 6 \\
Buzzards Bay & $\leq 12$ & $>12$ & 5 & 5 & 5 & 5 & 5 & 5 & 5 & 5 \\
Rhode Island & $\leq 13$ & $>13$ & 6 & 6 & 6 & 6 & 6 & 6 & 6 & 6
\end{tabular}


limitation introduces potential asymmetry in theoretical minimum and maximum values, the null hypothesis of no association (a theoretical mean of 0 ) remains valid because the average of the different values our index can take under any scenario (i.e. number of YoY and number of Juv) multiplied by the probability of each of these different outcomes (i.e. IA value of $x$ ) equals 0 . We excluded from the analysis sites with no YoY, those with no juveniles, and those where all quadrats were occupied by juveniles because the observed and expected proportions of YoY associated with juveniles at those sites were set and thus provide no information concerning YoY behavioural decisions. Between 2001 and 2008, these exclusion criteria eliminated 159 of 498 sites, of which between 1.9 and $14.0 \%$ were sites in different years that contained neither settlers nor juveniles, between 5.7 and $22.0 \%$ contained juveniles but no settlers, and between 0 and $4.0 \%$ contained settlers but no juveniles. We then evaluated, for each year separately ( $\sim 40$ sites remaining per year after filtering) as well as for all 8 years pooled, the statistical null hypothesis that the mean IA across sites differed significantly from 0 using a 1 -sample $t$-test $(\alpha=0.05)$.

\section{Behavioural experiments}

Juvenile lobster (20 to $30 \mathrm{~mm}$ ) were collected in mid-coast Maine by SCUBA divers and held in flowthrough aquaria at the University of Maine's Darling Marine Centre, Walpole, Maine. Lobsters were fed a diet of frozen shrimp every other day. Postlarval lobsters were obtained from the Zone $\mathrm{C}$ lobster hatchery in Stonington, Maine, and transported to the Darling Marine Centre. Postlarvae were maintained individually in $5 \mathrm{~cm}$ diameter $\times 10 \mathrm{~cm}$ long cylindrical containers in flow-through aquaria with filtered $(20 \mu \mathrm{m})$ ambient seawater. Postlarvae were fed frozen brine shrimp once daily. Water temperature and salinity were recorded daily and fluctuated between 16 and $18^{\circ} \mathrm{C}$ and 28 and 30 , respectively.

To evaluate the settlement response of postlarvae to the presence of juveniles, we conducted 2 sets of experiments, termed 'short term' and 'long term', in clear plastic 261 aquaria with a sand-covered bottom. We used sand instead of cobble substrate to increase postlarval exploration behaviour and assess how the latter is affected by the presence of juveniles; in laboratory settings, competent postlarvae tend to settle rapidly if cobble substrate is available. Settlement and metamorphosis in the American lobster are separate events; Stage III larval lobster moult and metamorphose into postlarval lobster, which only become competent to settle approximately halfway through the postlarval stage. In both types of experiments, we observed bottom-searching behaviour of individual postlarvae in the presence or absence of juveniles. In short-term experiments, we evaluated bottom-searching behaviour as the proportion of time, over a 4 min period, that individual larvae spent near the bottom, starting immediately following their introduction to the aquarium. In the long-term experiments, we observed bottom-searching behaviour for a 2 min period every $6 \mathrm{~h}$ over a $24 \mathrm{~h}$ period and then estimated for each observation period the proportion of postlarvae that spent most of their time near the bottom. Experiments were completed between August and September 2008.

In total, we completed 47 replicates of the treatment with juveniles present and 48 control trials where juveniles were absent for both the short-term and the long-term experiments. Postlarvae were obtained from the hatchery by combining a mixture of several mothers' broods, which we distributed haphazardly into experimental treatments. Temperature ranged from 18 to $20^{\circ} \mathrm{C}$ as recorded at the beginning and end of each trial.

We initially tested homogeneity of replicates within each treatment using 2-way models with Replicate and Treatment as factors, to determine whether replicates could be pooled (Sokal \& Rohlf 1981). A trial represents a set of experiments on one particular day, and a batch represents a group of postlarvae obtained from the hatchery at the same time. Treatments were randomly assigned to trials, and because each batch of larvae mixed multiple broods, we considered them unbiased. We randomized the sequence of experimental replicates, conducting 8 replicates simultaneously during a trial. We calculated the proportion of postlarvae that settled in the presence of older conspecifics by dividing the number of settled postlarvae by the total number of replicates for each treatment. For short-term experiments, we evaluated (1) the proportion of time spent on the bottom for each trial, (2) the time until the initial dive, and (3) the total number of dives to the bottom. We conducted separate analyses for each of these variables using a $t$-test with equal variance. For long-term experiments, we examined the effect of the presence of conspecific juveniles on postlarval settlement (dependent variable) using a binary logistic regression with Treatment (2 levels: Juv presence vs. absence), Time (5 levels: 0, 6, 12, 18, and $24 \mathrm{~h}$ ), and their interaction (Treatment $\times$ Time) as factors. 


\section{RESULTS}

\section{Field settlement time series}

As might be expected, the factors Year, Region, and Site [Region] all explained significant variability in YoY density (Table 2). The significant 3-way interaction between Juv density, Region, and Year indicated that covariate and main effects could not be interpreted independently of one another (Table 2). The highly significant model covariate also indicated strong association between YoY density and Juv density (Table 2). Note that we could not assess the interaction between Year and Site [Region] because not all sites were sampled in all years. VCA (Table 3) allowed us to determine what proportion of the variance in settler density was associated with each of the 3 spatial scales (Region, Site [Region], Quadrat). Because this model comprises Region and Site [Region] as random effect variables, the error term represents variability not explained by the 2 factors (Region and Site [Region]) and thus describes variability between quadrats from the same site of a given region. Results of the VCA were consistent across all 8 years surveyed. While we observed significant variability in YoY density among regions and sites (as per the earlier nested AN-

Table 2. Nested ANCOVA to determine the effect of Year, Region, Site [Region] and Juv density (a covariate) on the dependent variable YoY density

\begin{tabular}{|lrrccc|}
\hline Factor & SS & df & MS & $F$ & $p$ \\
\hline Region & 6.92 & 7 & 0.99 & 2.43 & 0.033 \\
Site [Region] & 19.54 & 48 & 0.41 & 7.27 & $<0.0001$ \\
Year & 0.91 & 7 & 0.13 & 2.32 & 0.023 \\
Year $\times$ Region & 8.05 & 49 & 0.16 & 2.93 & $<0.0001$ \\
Juv & 1.85 & 1 & 1.85 & 33.12 & $<0.0001$ \\
Juv $\times$ Region & 1.53 & 7 & 0.22 & 3.9 & 0.0003 \\
Juv $\times$ Year & 0.31 & 7 & 0.04 & 0.79 & 0.594 \\
Juv $\times$ Region $\times$ Year & 3.8 & 49 & 0.08 & 1.39 & 0.039 \\
Error & 276.52 & 4939 & 0.06 & & \\
\hline
\end{tabular}

Table 3. Variance component analysis to partition the proportion of variance in settler density across 3 spatial scales. Regions versus Sites within a Region, and Quadrats. 'Quadrat' variable reflects the variability among quadrats from a single site

\begin{tabular}{|lccccccccc|}
\hline \multirow{2}{*}{ Variable } & \multicolumn{8}{c|}{ Percent of total variance by year } & \\
\cline { 2 - 10 } & 2001 & 2002 & 2003 & 2004 & 2005 & 2006 & 2007 & 2008 & Average \\
\hline Region & 16.6 & 10.2 & 13.2 & 13 & 10.2 & 5.3 & 15.6 & 10.7 & 11.9 \\
Site [Region] & 11.4 & 13.9 & 17.5 & 11.2 & 14 & 15.5 & 11.5 & 14.8 & 13.7 \\
Quadrat & 72 & 75.9 & 69.4 & 75.8 & 75.8 & 79.2 & 72.9 & 74.4 & 74.4 \\
\hline
\end{tabular}

COVA), much more of the variance occurred among quadrats sampled at the same site than between quadrats taken in different regions or different sites within the same region (Table 3). We observed similar variability in YoY density among Regions and Sites [Regions].

Separate regression analyses clearly indicated why the ANCOVA interaction was significant, in that the relationship between Juv density and YoY density differed markedly among years for the 8 study regions. When aggregating data by region, regression analyses showed that YoY recruitment strongly associated with Juv densities for all 8 years of the analysis (Fig. 2). Regional averages of YoY density ranged from 0 to 1.1 individuals per $0.5 \mathrm{~m}^{2}$, whereas Juv density ranged from 0.02 to 2.8 individuals per $0.5 \mathrm{~m}^{2}$. Consistently high densities of both YoY and Juv in the mid-coast Maine region contrasted Buzzards Bay, where densities were consistently among the lowest observed (R. A. Wahle unpubl. data).

Disaggregating the data to examine among-site variability revealed a similarly strong positive association between YoY and Juv across all study sites (Fig. 3), although the relationship was less consistent when examined separately for each region (Table 4). For example, in mid-coast Maine, YoY significantly associated with Juv lobsters in all years except 2006. Similarly, the association was significant for 6 of 8 years in the Casco Bay region, which neighbours the mid-coast region. In contrast, we observed fewer significant associations for the 2 more northern regions (only 2 out of 8 years in both cases) as well as the 4 more southerly regions (between 1 and 4 years for the York region).

Analysis of the site-specific IA showed that the mean IA across sites was significantly greater than 0 when pooling all 8 years of data (Table 5) and also in 6 of 8 years when we analysed years separately (Fig. 4, Table 5). These results indicate that YoY positively associated with Juv lobsters at the quadrat scale within sites.

\section{Behavioural experiments}

During the 4 min observations of the short-term experiment, postlarvae spent significantly more time on the bottom of the aquarium in the presence than in the absence of conspecific juveniles $\left(t_{94}=2.36, \mathrm{p}=0.01\right.$, Fig. 5). However, there was no statistically significant difference between 


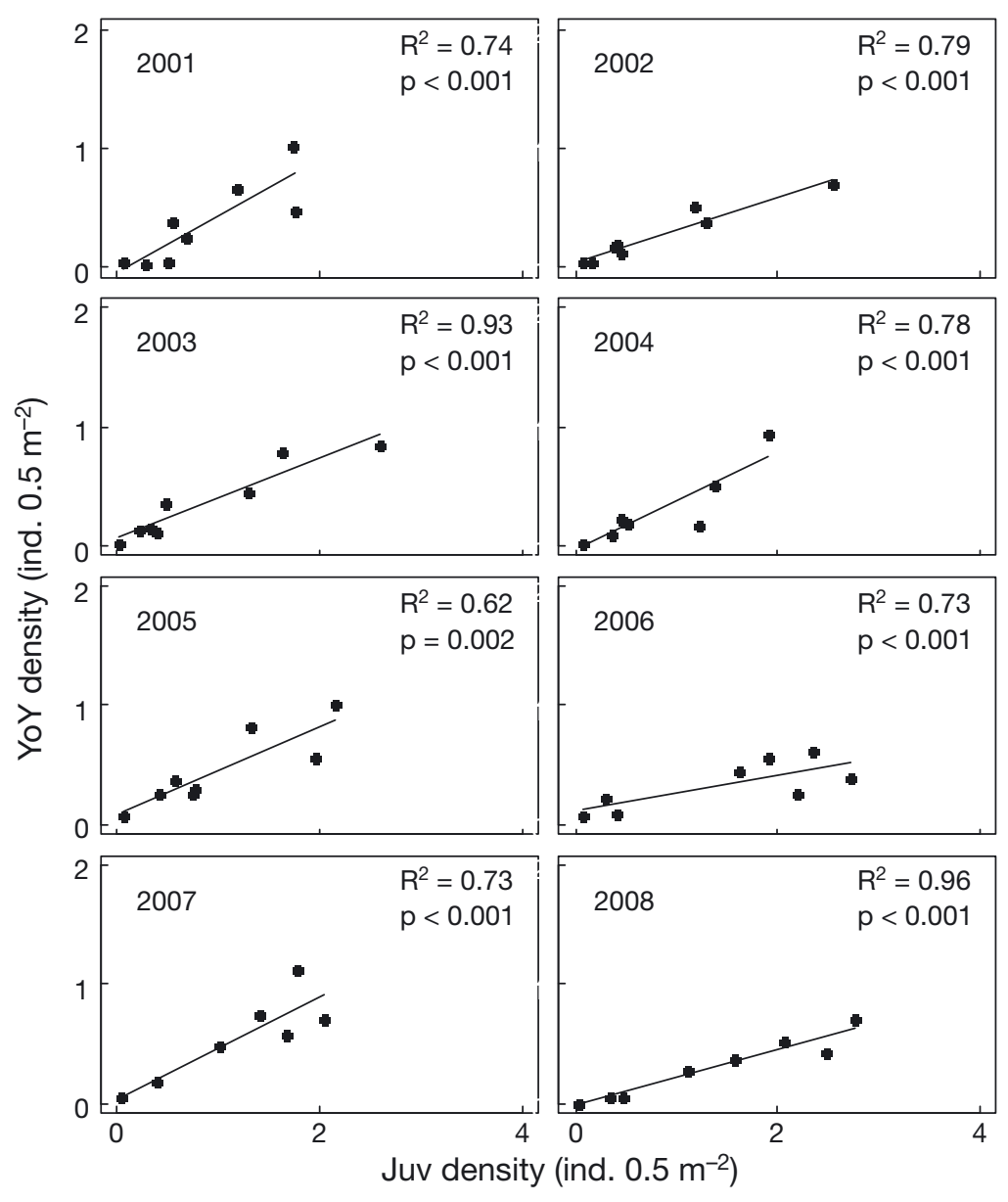

Fig. 2. Homarus americanus. Scatterplots and regression analyses for the relationship between the regional mean density of YoY and Juv lobsters at 8 regions sampled from 2001 to 2008. Data were aggregated by region and square-root transformed prior to analysis. Plotted data are untransformed

kilometres (among regions). Potential mechanisms to account for high correlations between YoY recruitment and established benthic conspecifics vary, depending on scale. Multi-scale assessment of recruitment patterns offers a powerful tool for understanding the processes that influence those mechanisms. At large spatial scales, positive relationships between YoY and Juv most likely arise from physical processes, such as consistent circulationdriven differences in larval supply (Wahle \& Incze 1997, Incze \& Naimie 2000, Xue et al. 2008). The importance of oceanography as a driver of recruitment patterns has been well documented over the last century in that environmental factors, such as offshore advection, can have significant impact on recruitment patterns (Bailey 1981, Roughgarden et al. 1988). Nonetheless, behavioural mechanisms, such as active behavioural selection for suitable habitat (Butman 1987) and attraction to conspecifics (Burke 1986), become increasingly important at smaller spatial scales.

The highly significant ANCOVA model covariate strongly indicates that YoY density strongly correlates with Juv density. We therefore examined this association further at different spatial scales and developed an approach

the control and Juv treatments in either the number of postlarval dives to the bottom $\left(t_{95}=0.23, \mathrm{p}=0.41\right.$, Fig. 5) or the time until the initial dive $\left(t_{95}=0.10, \mathrm{p}=\right.$ 0.46, Fig. 5).

In the long-term experiment (Fig. 6, Table 6), settlement by postlarvae was significantly affected by time ( $p<0.001)$, increasing markedly over the first $6 \mathrm{~h}$ of the experiment and then remaining more or less stable over the remaining $18 \mathrm{~h}$. However, settlement was not significantly affected by Treatment $(\mathrm{p}=0.41)$ or by the Time $\times$ Treatment interaction $(\mathrm{p}=0.18)$.

\section{DISCUSSION}

The long-term settlement index demonstrates strong positive relationships between YoY and Juv densities at scales of metres (quadrats) to hundreds of to test for potential effects of behavioural processes at small spatial scales.

Multiple studies document the importance of larval supply in determining settlement variation among sites, but large-scale environmental effects confound our ability to evaluate the significance of small-scale mechanisms, particularly behavioural effects (Bertness et al. 1992). Furthermore, the significance of density-dependent interactions (i.e. cannibalism and competition) are likely more prevalent in areas with a greater larval supply (Roughgarden et al. 1988). Topographically mediated ocean processes can influence patterns of variation at meso-scales of 1 to $10 \mathrm{~km}$ (e.g. upwelling or onshore/offshore winds) (Ebert \& Russel 1988, Archambault \& Bourget 1999, Palma et al. 2006), as can suitability of benthic habitat (Moksnes et al. 1997). These factors influence both larval supply (Pile et al. 1996) and successful settlement (Pile et al. 1996, Pineda et al. 2009). For 

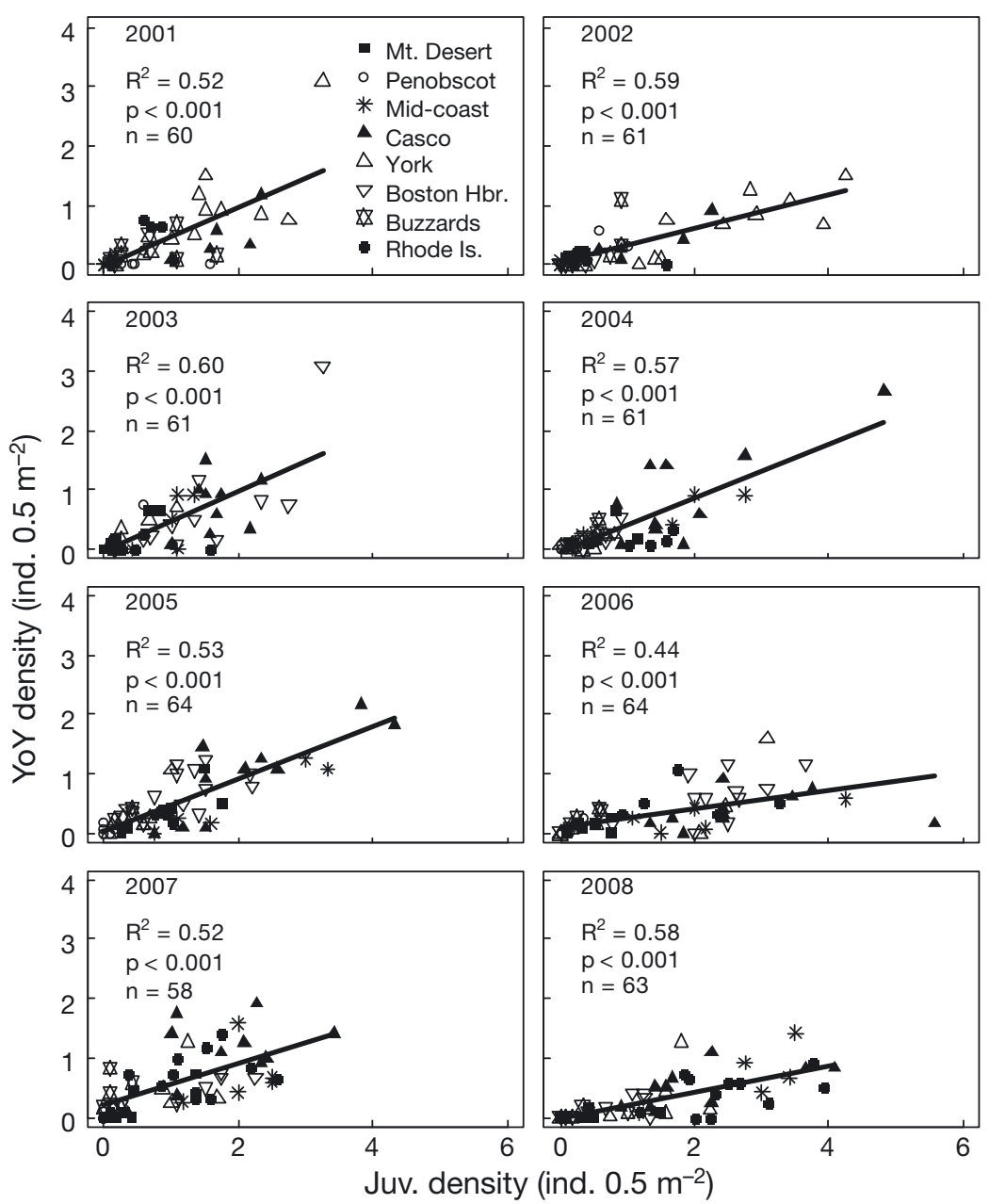

Fig. 3. Homarus americanus. The relationship between YoY and Juv lobsters for the pooled 58 to 64 sites sampled among the 8 regions from 2001 to 2008. Regression results for individual regions are shown in Table 4. Data were aggregated by site and square-root transformed prior to regression analysis. Plotted data are untransformed example, Wahle \& Incze (1997) related consistent annual differences in lobster recruitment on 2 sides of a small island (4 $\mathrm{km}$ long) to wind-driven circulation. Over time, spatial differences in the population density within cohorts disappeared, presumably because as individuals in a cohort aged, they became increasingly mobile and effectively decoupled the settler-to-recruit spatial relationship.

In our study, YoY significantly associated with Juv for the mid-coast region for all years except 2006, although results were generally non-significant for the more southern Buzzards Bay region. Low recruitment may explain some of the non-significant associations between YoY and Juv densities. For example, the typically strong mid-coast recruitment (highest regional average in 6 out of 8 years) contrasted the relatively low recruitment in Buzzard's Bay (lowest regional average in all years) (R. A. Wahle unpubl. data), and poor recruitment ( $50 \%$ less than its 8 yr average) marked the one year in which the mid-coast result was non-significant (2006). Average annual recruitment at each site fluctuated between 0.38 and 1.12 individuals per $0.5 \mathrm{~m}^{2}$ and between 0 and 0.06 individuals per $0.5 \mathrm{~m}^{2}$, respectively.

At smaller scales, the American lobster is a useful model organism to examine the influence of potential attractants on postlarval settlement because benthic juveniles remain within structurally complex nurseries for the first few years of life (Incze \& Wahle 1991, Cowan et al. 2001, Wahle 2003). The quadrat-scale analysis of the YoY-to-Juv relationship indicated potentially important associations between juvenile and YoY lobster at very small spatial scales that largescale hydrodynamic processes cannot explain. The VCA shows that the largest variance in settler density across the 3 spatial scales occurred at the quadrat level. This pattern points to the importance of small-scale processes, 
although further analyses will be necessary to determine how much of this variability is deterministic versus stochastic. Nevertheless, the IA developed here does provide a mechanism to assess whether the association between YoY and Juv at small spatial scales is greater than expected by chance.

Table 5. One-sample $t$-test to determine whether the observed mean index of association (IA) across sites is significantly different from 0 , for all years combined and for each year separately

\begin{tabular}{|lrrrcrrc|}
\hline Year & $\mathrm{n}$ & Mean IA & $\begin{array}{c}\text { Lower } \\
95 \% \text { CI }\end{array}$ & $\begin{array}{c}\text { Upper } \\
95 \% \text { CI }\end{array}$ & $t$ & df & $\mathrm{p}$ \\
\hline All & 339 & 8.75 & 5.77 & 11.78 & 5.68 & 338 & $<0.0001$ \\
2001 & 38 & 7.58 & -2.84 & 18 & 1.47 & 37 & 0.149 \\
2002 & 40 & 11.89 & 2.34 & 21.44 & 2.52 & 39 & 0.016 \\
2003 & 38 & 10.01 & 0.28 & 19.76 & 2.08 & 37 & 0.044 \\
2004 & 46 & 11.28 & 0.87 & 21.7 & 2.18 & 45 & 0.034 \\
2005 & 48 & 8.45 & 1.18 & 15.72 & 2.34 & 47 & 0.024 \\
2006 & 40 & 12.53 & 3.26 & 21.79 & 2.74 & 39 & 0.009 \\
2007 & 53 & 8.66 & 2.65 & 14.68 & 2.89 & 52 & 0.006 \\
2008 & 36 & -1.70 & -9.78 & 6.37 & -0.43 & 35 & 0.671 \\
\hline
\end{tabular}

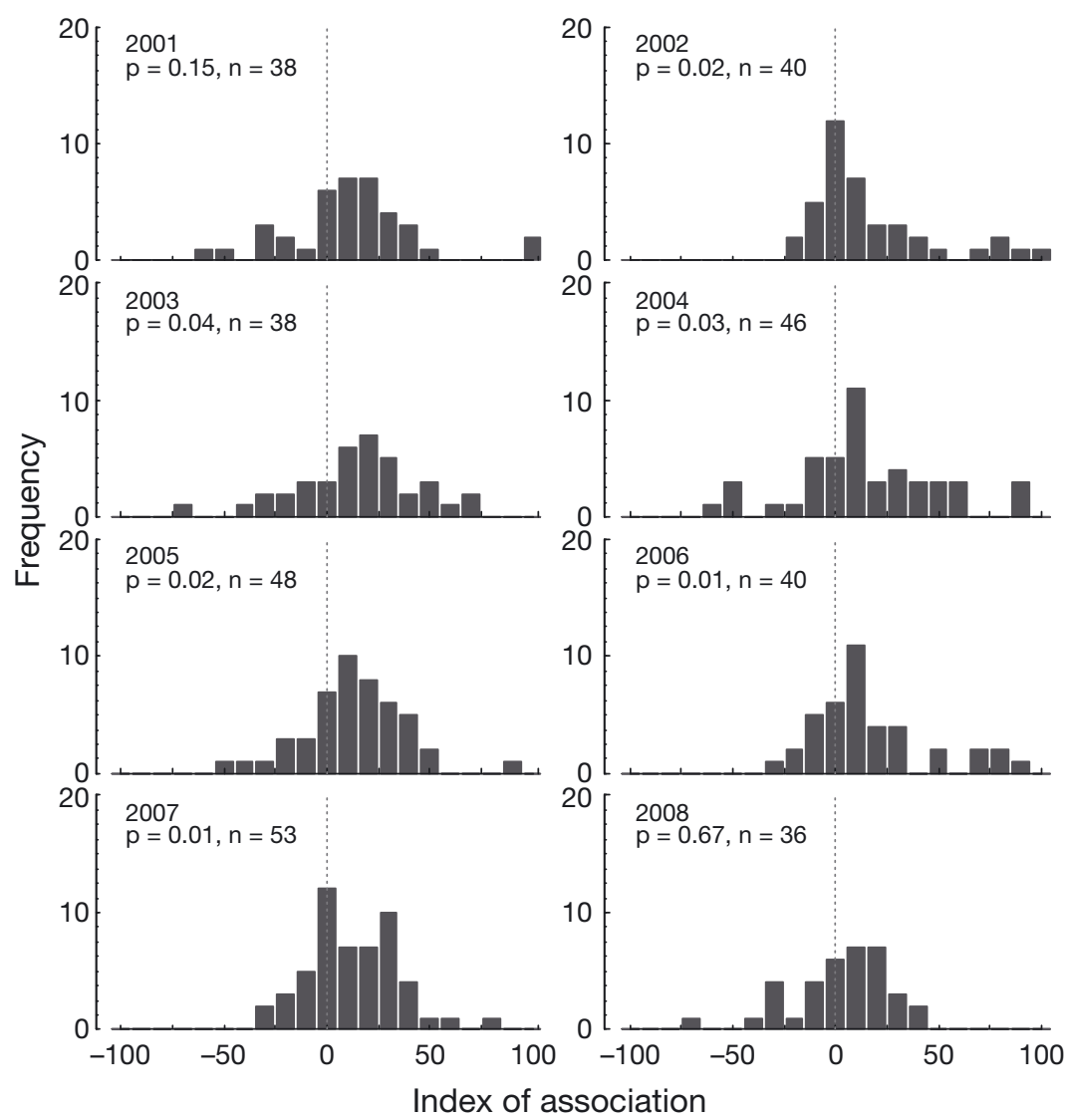

Fig. 4. Homarus americanus. Index of association (see 'Materials and methods: Field settlement time series') describing the level of association between YoY and Juv American lobsters. Vertical dashed line denotes hypothesized mean. (See Table 5 for statistical summaries)
Postlarval lobsters were more likely to settle in quadrats with at least 1 conspecific juvenile than in quadrats with none, either when data from all years were analysed together or for 6 of 8 years when analysed separately. These analyses reflect associations at the scale of metres to 10 s of metres because we derived each datum by contrasting the distribution of settlers with that of juveniles across quadrats within a site. This intra-site, quadrat-level association most likely results from postlarval behavioural decisions rather than hydrodynamic processes because variability in supply at the quadrat scale differs greatly across years and juvenile movement on the seafloor undoubtedly modifies quadrat-scale patterns established at settlement.

Interestingly, the number of sites with settlers that were excluded from these analyses because they had no juveniles was very low (0 to $4 \%$ of all sites in different years), indicating that the association we report not only reveals small-scale behavioural processes but also speaks to largescale patterns of association of settlers with juveniles, as the vast majority of sites that had settlers also had juveniles. The number of sites excluded because of the absence of settlers in our quadrats was higher, both in the absence (1.9 to $14 \%$ ) and presence (5.7 to $22 \%$ ) of juveniles, suggesting YoY do not settle in all areas where adequate substrate occurs and that in any given year certain areas harbouring juveniles do not receive a new supply of postlarvae. The association between juvenile and settler densities at the quadrat scale may result from postlarval attraction to conspecifics or some other aspect of the habitat. While additional field surveys at small spatial scales with YoY and Juv lobsters may reveal whether settler and juvenile densities correlate strongly with particular habitat features in different quadrats, experimental studies (in the lab or the field) will ultimately be necessary to elucidate the mechanism underlying the 


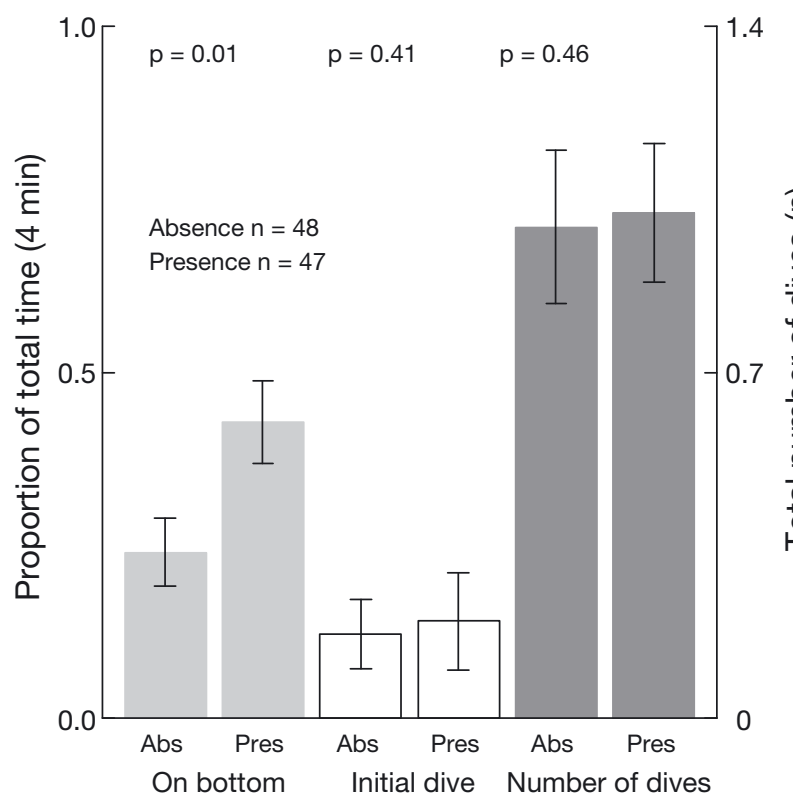

Fig. 5. Homarus americanus. Response of YoY in short-term (4 min) experiments to the Juv (present) and control (absent) treatments, as determined by the mean $( \pm 1 \mathrm{SE})$ proportion of time spent on the bottom of the aquarium (left axis), proportion of time until the initial dive (left axis), and number of dives (right axis)

association between YoY and Juv lobsters at these small spatial scales.

Short-term laboratory experiments showed that postlarvae spent significantly more time on the bottom of aquaria in the presence of juveniles, supporting our interpretation of the quadrat-scale field result that behaviour contributes to this relationship. Conspecific attraction is consistent with laboratory observations of swimming postlarvae orienting toward conspecific odour plumes (Boudreau et al. 1993). Positive response to and settlement near conspecifics could provide a mechanism to locate suitable habitat (sea urchins: Tegner \& Dayton 1977, barnacles: Crisp 1985, Jeffery 2000, crab: Gebauer et al. 2002, Vadas \& Elner 2003), and reduced search time at the time of settlement may provide a post-settlement fitness benefit (Fletcher 2006). Conspecifics influenced postlarval recruitment of gregarious spiny lobster Panulirus argus (Zito-Livingston \& Childress 2009), either as a result of reduced duration of the planktonic phase because postlarvae use conspecific odours to quickly locate a shelter or through higher survival probability of aggregations of juveniles that may be less vulnerable to predation (Estrella \& McKiernan 1989, Briones-Fourzán \& Lozano-Alvarez 2008).

Given that our long-term behavioural experiments did not show a significant difference between treat-

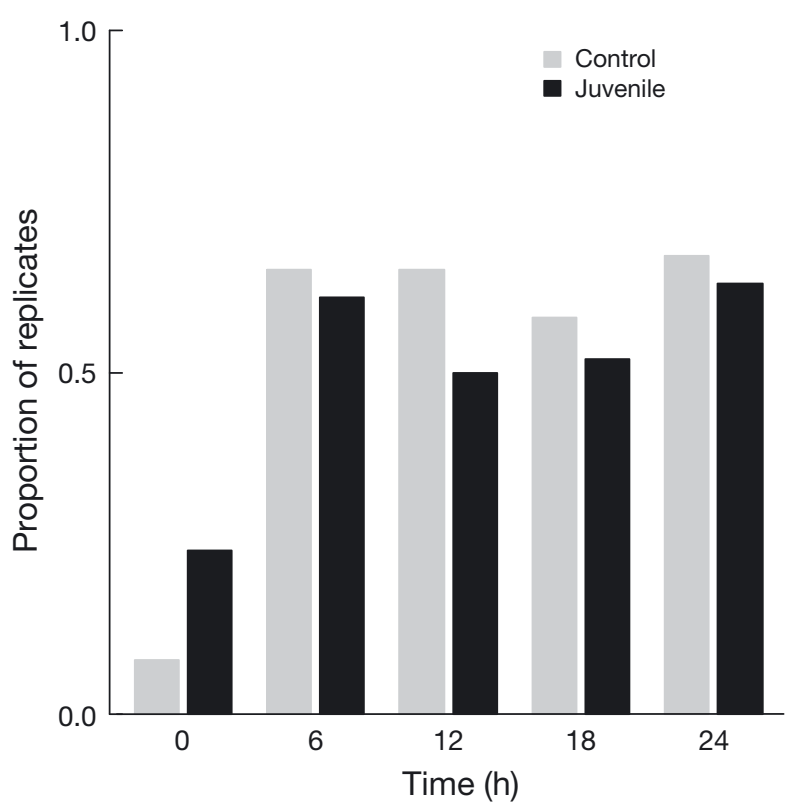

Fig. 6. Homarus americanus. Response of YoY in longterm experiments to the Juv $(n=47)$ and control $(n=48)$ treatments as determined by the proportion of postlarvae that had settled in each time increment, as assessed over a 2 min observation period. See Table 6 for statistical analysis

Table 6. Logistic regression from long-term experiment to determine the effect of the presence of juveniles on postlarval settlement

\begin{tabular}{|lrcrc|}
\hline & Estimate & $\mathrm{SE}$ & $Z$ & $\mathrm{p}$ \\
\hline Intercept & -0.85 & 0.24 & -3.58 & $<0.001$ \\
Treatment & 0.28 & 0.34 & 0.83 & 0.41 \\
Time & 0.08 & 0.02 & 4.70 & $<0.001$ \\
Interaction & -0.03 & 0.02 & -1.33 & 0.18 \\
\hline
\end{tabular}

ments, it is possible that other aspects of the habitat in the experimental tanks were not suitable for postlarvae to remain on the bottom. In natural environments, determining a suitable settlement location probably depends on multiple sensory cues. A hierarchy of cues may be necessary for settlement and final establishment in nursery habitat (Kingsford et al. 2002, Ettinger-Epstein et al. 2008). In the context of our results, the presence of juveniles may induce or intensify postlarval searching behaviour, but if suitable habitat is absent, larvae may delay settlement. Thus, behavioural experiments that simultaneously offer conspecifics and suitable cobble habitat might yield a more persistent settlement response. Latestage megalopae of the crab Chasmagnathus granulata accelerated metamorphosis significantly when 
simultaneously exposed to natural mud and conspecific odour than when exposed to either cue in isolation (Gebauer et al. 1998).

The possibility that postlarval Homarus americanus may also respond positively to conspecifics is surprising given that clawed lobsters are not generally gregarious. For species susceptible to cannibalism or increased competition, these risks must outweigh the risk of arriving in unfavourable habitat (Donahue 2006). While cannibalism is known to occur in laboratory conditions for the American lobster, its significance for recruitment dynamics remains poorly understood (Wahle et al. 2001, Wahle 2003). Field enclosure experiments with densities representative of the high end of the naturally observed range suggest a negligible impact of older conspecifics on YoY growth or survival (Wahle et al. 2001).

Our study highlights the importance of addressing ecological questions at multiple scales to tease apart patterns and processes governing recruitment (Butman 1987). Our quadrat-level correlation supports the importance of behaviour over large-scale spatial processes in causing spatial patterns of recruitment. In particular, it suggests that postlarvae respond to settlement cues that may include conspecific juveniles, a suggestion which our lab experiments support, or at least seek similar microhabitats as conspecific juveniles. This question warrants further investigation, such as settlement experiments that manipulate conspecific cues and substrate characteristics for various stages of settling postlarvae.

The costs and benefits of settling among conspecifics warrants further investigation to determine the degree to which habitat selection choices may be based on a combination of positive and negative interactions, the degree to which these interactions are density dependent (Hunt \& Scheibling 1997), and how patch size might influence these cues (Fletcher 2006). Whereas mobile species can potentially 'reverse' a settlement decision, there is little information on the extent of post-settlement movement to 'correct' for settlement mistakes.

\section{SUMMARY}

Our study uses a multi-scale approach that pairs lab and field experiments to investigate the interaction of processes that function at different spatial scales and the degree to which recruitment reflects these processes. Hydrographic conditions likely set larval supply at large spatial scales; however, our results show that behavioural responses to some habitat-quality cue, potentially conspecifics, may operate at the finest scales. The behavioural experiments reported here, in combination with the quadrat-scale results from the long-term data set, suggest that juvenile presence may help to explain spatial variability in recruitment of the American lobster, despite potentially negative effects that lobsters may have on each other after settlement. An understanding of how organisms interpret and respond to multiple, sometimes conflicting cues, such as conspecific effects in combination with variable sheltering quality, may provide more insight into the behavioural mechanisms by which postlarvae search for and select suitable habitat.

Acknowledgements. Data from the American Lobster Settlement Index for the 2001 to 2008 time period were collected by Maine Department of Marine Resources, Massachusetts Division of Marine Fisheries, and Rhode Island Division of Fish and Wildlife. We thank the staff at University of Maine's Darling Marine Center for their help with logistics as well as the Maine Lobster Zone C Lobster Hatchery, Stonington, ME, Lobster Hatchery for kindly supplying lobster larvae. An earlier version of this manuscript benefitted from comments from A. Mercier, B. deYoung, and 3 anonymous reviewers. This work was supported by a National Oceanic and Atmospheric Administration - Northeast Consortium grant to R.A.W., a Natural Sciences and Engineering Research Council of Canada (NSERC) Discovery Grant to P.V.R.S., and NSERC and Memorial University Graduate Fellowships to V.B.C.

\section{LITERATURE CITED}

Aiken DE, Waddy SL (1980) Reproductive biology. Academic Press, New York, NY

Archambault P, Bourget E (1999) Influence of shoreline configuration on spatial variation of meroplanktonic larvae, recruitment and diversity of benthic subtidal communities. J Exp Mar Biol Ecol 238:161-184

Bailey KM (1981) Transport and recruitment of Pacific hake Merluccius productus. Mar Ecol Prog Ser 6:1-9

> Bertness MD, Gaines SD, Stephens EG, Yund PO (1992) Components of recruitment in populations of the acorn barnacle Semibalanus balanoides (Linnaeus). J Exp Mar Biol Ecol 156:199-215

Boudreau B, Bourget E, Simard Y (1993) Behavioural responses of competent lobster postlarvae to odor plumes. Mar Biol 117:63-69

> Briones-Fourzán P, Lozano-Alvarez E (2008) Coexistence of congeneric spiny lobsters on coral reefs: differences in conspecific aggregation patterns and their potential antipredator benefits. Coral Reefs 27:275-287

Burke RD (1986) Pheromones and the gregarious settlement of marine invertebrate larvae. Bull Mar Sci 39:323-331

Butman CA (1987) Larval settlement of soft-sediment invertebrates: the spatial scales of pattern explained by active habitat selection and the emerging role of hydrodynamical processes. Oceanogr Mar Biol Annu Rev 25:113-165 Butman CA, Grassle JP, Webb CM (1988) Substrate choices 
made by marine larvae settling in still water and in a flume flow. Nature 333:771-773

> Caley MJ, Carr MH, Hixon MA, Hughes TP, Jones GP, Menge BA (1996) Recruitment and the local dynamics of open marine populations. Annu Rev Ecol Evol Syst 27: 477-500

Childress MJ, Herrnkind WF (2001) Influence of conspecifics on the ontogenetic habitat shift of juvenile Caribbean spiny lobsters. Mar Freshw Res 52:1077-1084

> Connell JH (1961) The influence of interspecific competition and other factors on the distribution of the barnacle Chthamallus stellatus. Ecology 42:710-723

> Connell JH (1985) The consequences of variation in initial settlement vs. post-settlement mortality in rocky intertidal communities. J Exp Mar Biol Ecol 93:11-45

Cooper RA, Uzmann JR (1980) Ecology of juvenile and adult Homarus. In: Cobb JS, Phillips BF (eds) The biology and management of lobsters, Vol II. Ecology and management. Academic Press, New York, NY, p 97-142

> Cowan DF, Solow AR, Beet A (2001) Patterns in abundance and growth of juvenile lobster, Homarus americanus. Mar Freshw Res 52:1095-1102

Crisp DG (1985) Recruitment of barnacle larvae from the plankton. Bull Mar Sci 37:478-486

$>$ Donahue MJ (2006) Allee effects and conspecific cueing jointly lead to conspecific attraction. Oecologia 149: 33-43

$>$ Dworjanyn SA, Pirozzi I (2008) Induction of settlement in the sea urchin Tripneustes gratilla by macroalgae, biofilms and conspecifics: a role for bacteria? Aquaculture 274: 268-274

- Ebert TA, Russel MP (1988) Latitudinal variation in size structure of the West Coast purple sea urchin: a correlation with headlands. Limnol Oceanogr 33:286-294

Estrella BT, McKiernan DJ (1989) Catch-per-unit-effort and biological parameters from the Massachusetts coastal lobster (Homarus americanus) resource: description and trends. In: NOAA Technical Report NMFS Vol 81

Etherington LL, Eggleston DB (2000) Large-scale blue crab recruitment: linking postlarval transport, post-settlement planktonic dispersal, and multiple nursery habitats. Mar Ecol Prog Ser 204:179-198

Ettinger-Epstein $\mathrm{P}$, Whalan S, Battershill CN, de Nys R (2008) A hierarchy of settlement cues influences larval behaviour in a coral reef sponge. Mar Ecol Prog Ser 365: 103-113

Fletcher RJ Jr (2006) Emergent properties of conspecific attraction in fragmented landscapes. Am Nat 168: 207-219

> Gebauer P, Walter I, Anger K (1998) Effects of substratum and conspecific adults on the metamorphosis of Chasmagnathus granulata (Dana) (Decapoda: Grapsidae) megalopae. J Exp Mar Biol Ecol 223:185-198

Gebauer P, Paschke K, Anger K (2002) Metamorphosis in a semiterrestrial crab, Sesarma curacaoense: intra- and interspecific settlement cues from adult odors. J Exp Mar Biol Ecol 268:1-12

> Head RM, Berntsson KM, Dahlstrom M, Overbeke K, Thomason JC (2004) Gregarious settlement in cypris larvae: the effect of cyprid age and assay duration. Biofouling 20:123-128

Hewitt JE, Legendre P, McArdle BH, Thrush SF, Bellehumeur C, Lawrie SM (1997) Identifying relationships between adult and juvenile bivalves at different spatial scales. J Exp Mar Biol Ecol 216:77-98
Howard AE, Nunny RS (1983) Effects of near-bed current speeds on the distribution and behaviour of the lobster, Homarus gammarus (L.). J Exp Mar Biol Ecol 71:27-42

Hunt HL, Scheibling RE (1997) Role of early post-settlement mortality in recruitment of benthic marine invertebrates. Mar Ecol Prog Ser 155:269-301

Incze LS, Naimie CE (2000) Modelling the transport of lobster (Homarus americanus) larvae and postlarvae in the Gulf of Maine. Fish Oceanogr 9:99-113

Incze LS, Wahle RA (1991) Recruitment from pelagic to early benthic phase in lobsters Homarus americanus. Mar Ecol Prog Ser 79:77-87

Incze LS, Wahle RA, Cobb JS (1997) Quantitative relationships between postlarval production and benthic recruitment in lobsters, Homarus americanus. Mar Freshw Res 48:729-743

Jeffery CA (2000) Settlement in different-sized patches by the gregarious intertidal barnacle Chamaesipho tasmanica Foster and Anderson in New South Wales. J Exp Mar Biol Ecol 252:15-26

Jensen GC (1989) Gregarious settlement by megalopae of the porcelain crabs Petrolisthes cinctipes (Randall) and P. eriomerus Stimpson. J Exp Mar Biol Ecol 131: 223-231

Jensen RA, Morse DE (1984) Intraspecific facilitation of larval recruitment: gregarious settlement of the polychaete Phragmatopoma californica (Fewkes). J Exp Mar Biol Ecol 83:107-126

Keough MJ, Downes BJ (1982) Recruitment of marine invertebrates: the role of active larval choices and early mortality. Oecologia 54:348-352

Kimmerer WJ, McKinnon AD (1987) Zooplankton in a marine bay. II. Vertical migration to maintain horizontal distributions. Mar Ecol Prog Ser 41:53-60

Kingsford MJ, Leis JM, Shanks A, Lindeman KC, Morgan SG, Pineda J (2002) Sensory environments, larval abilities, and local self-recruitment. Bull Mar Sci 70:309-340

> Krug PJ, Zimmer RK (2004) Developmental dimorphism: consequences for larval behavior and dispersal potential in a marine gastropod. Biol Bull 207:233-246

> Lavalli KL, Barshaw DE (1986) Burrows protect postlarval lobsters Homarus americanus from predation by the nonburrowing cunner Tautogolabrus adspersus, but not from the burrowing mud crab Neopanope texani. Mar Ecol Prog Ser 32:13-16

Lawton P, Lavalli KI (1995) Larval and postlarval ecology. In: Factor JF (ed) Biology of the lobster Homarus americanus. Academic Press, San Diego, CA, p 47-88

Menge BA (1992) Community regulation: Under what conditions are bottom-up factors important on rocky shores? Ecology 73:755-765

Metaxas A (2001) Behaviour in flow: perspectives on the distribution and dispersion of meroplanktonic larvae in the water column. Can J Fish Aquat Sci 58:86-98

> Moksnes PO (2004) Self-regulating mechanisms in cannibalistic populations of juvenile shore crabs Carcinus maenas. Ecology 85:1343-1354

> Moksnes PO, Lipcius RN, Pihl L, van Montfrans J (1997) Cannibal-prey dynamics in young juveniles and postlarvae of the blue crab. J Exp Mar Biol Ecol 215:157-187

> O'Connor NJ, Richardson DL (1998) Attachment of barnacle (Balanus amphitrite Darwin) larvae: responses to bacterial films and extracellular materials. J Exp Mar Biol Ecol 226:115-129

> Paine RT, Levin SA (1981) Intertidal landscapes: disturbance 
and the dynamics of pattern. Ecol Monogr 51:145-178

Palma AT, Wahle RA, Steneck RS (1998) Different early post-settlement strategies between American lobsters Homarus americanus and rock crab Cancer irroratus in the Gulf of Maine. Mar Ecol Prog Ser 162:215-225

Palma AT, Pardo LM, Veas R, Cartes C and others (2006) Coastal brachyuran decapods: settlement and recruitment under contrasting coastal geometry conditions. Mar Ecol Prog Ser 316:139-153

Pawlik JR (1992) Chemical ecology of the settlement of benthic marine invertebrates. Oceanogr Mar Biol Annu Rev 30:273-335

> Pawlik JR, Butman CA, Starczak VR (1991) Hydrodynamic facilitation of gregarious settlement of a reef-building tube worm. Science 251:421-424

> Pearce CM, Scheibling RE (1990) Induction of settlement and metamorphosis in the sand dollar Echinaranchnius parma: evidence for an adult-associated factor. Mar Biol 107:363-369

$>$ Pechenik JA (1999) On the advantages and disadvantages of larval stages in benthic marine invertebrate life cycles. Mar Ecol Prog Ser 177:269-297

> Pile AJ, Lipcius RN, van Montfrans J, Orth RJ (1996) Density-dependent settler-recruit-juvenile relationships in blue crabs. Ecol Monogr 66:277-300

Pineda J (2000) Linking larval settlement to larval transport: assumptions, potentials, and pitfalls. In: Färber-Lorda J (ed) Oceanography of the eastern Pacific, Vol 1. CICESE, Ensenada, p 84-105

Pineda J, Reyns NB, Starczak VR (2009) Complexity and simplification in understanding recruitment in benthic populations. Popul Ecol 51:17-32

Raimondi PT (1991) Settlement behavior of Chthamalus anisopoma larvae largely determines the adult distribution. Oecologia 85:349-360

Roughgarden J, Gaines S, Possingham H (1988) Recruitment dynamics in complex life cycles. Science 241: 1460-1466

Scarratt DJ (1973) Abundance, survival, and vertical and diurnal distribution of lobster larvae in Northerhumberland Strait, 1962-63, and their relationships with commercial stocks. J Fish Res Board Can 30:1819-1824

Scheltema RS (1986) On dispersal and planktonic larvae of benthic invertebrates: an eclectic overview and summary of problems. Bull Mar Sci 39:290-322

Seed R, Wood V (1994) Recruitment and mortality of Alcyonidium hirsutum (Fleming) and Flustrellidra hispida (Fabricius) (Bryozoa: Ctenostomata) within a Fucus serratus L. community. Cah Biol Mar 35:305-326

Sheehy MRJ, Bannister RCA, Wickins JF, Shelton PMJ (1999) New perspectives on the growth and longevity of the European lobster (Homarus gammarus). Can J Fish Aquat Sci 56:1904-1915

Snelgrove PVR, Butman CA, Grassle JP (1993) Hydrodynamic enhancement of larval settlement in the bivalve Mulinia lateralis (Say) and the polychaete Capitella sp. I in microdepositional environments. J Exp Mar Biol Ecol 168:71-109

Sokal RR, Rohlf BL (1981) Biometry: the principle and practice of statistics in biological research. WH Freeman, San Francisco, CA

Editorial responsibility: Romuald Lipcius, Gloucester Point, Virginia, USA
Tamburri MN, Zimmer RK, Zimmer CA (2007) Mechanisms reconciling gregarious larval settlement with adult cannibalism. Ecol Modell 77:255-268

Tegner MJ, Dayton PK (1977) Sea urchin recruitment patterns and implications of commercial fishing. Science 196:324-326

Thrush SF, Cummings VJ, Dayton PK, Ford R and others (1997) Matching the outcome of small-scale density manipulation experiments with larger scale patterns: an example of bivalve adult/juvenile interactions. J Exp Mar Biol Ecol 216:153-169

> Vadas RL, Elner RW (2003) Responses to predation cues and food in two species of sympatric, tropical sea urchins. Mar Ecol 24:101-121

$>$ Vikebø F, Sundby S, Adlandsvik B, Fiksen Ø (2005) The combined effect of transport and temperature on distribution and growth of larvae and pelagic juveniles of Arcto-Norwegian cod. ICES J Mar Sci 62:1375-1386

> Wahle RA (2003) Revealing stock-recruitment relationships in lobsters and crabs: Is experimental ecology the key? Fish Res 65:3-32

> Wahle RA, Incze LS (1997) Pre- and post-settlement processes in recruitment of the American lobster. J Exp Mar Biol Ecol 217:179-207

> Wahle RA, Steneck RS (1991) Recruitment habitats and nursery grounds of the American lobster Homarus americanus: a demographic bottleneck? Mar Ecol Prog Ser 69: 231-243

Wahle RA, Steneck RS (1992) Habitat restrictions in early benthic life experiments on habitat selection and in situ predation with the American lobster. J Exp Mar Biol Ecol 157:91-114

> Wahle RA, Tully O, O'Donovan V (1996) Lipofuscin as an indicator of age in crustaceans: analysis of the pigment in the American lobster Homarus americanus. Mar Ecol Prog Ser 138:117-123

Wahle RA, Tully O, O'Donovan V (2001) Environmentally mediated crowding effects on growth, survival and metabolic rate of juvenile American lobsters (Homarus americanus). Mar Freshw Res 52:1157-1166

Wahle RA, Incze LS, Fogarty MJ (2004) First projections of American lobster fishery recruitment using a settlement index and variable growth. Bull Mar Sci 74:101-114

Wahle RA, Bergeron CE, Tremblay J, Wilson C and others (2013) The geography and bathymetry of American lobster benthic recruitment as measured by diver-based suction sampling and passive postlarval collectors. Mar Biol Res 9:42-58

Xue H, Incze L, Xu D, Wolff N, Pettigrew N (2008) Connectivity of lobster populations in the coastal Gulf of Maine: Part I: circulation and larval transport potential. Ecol Modell 210:193-211

> Young CM (1988) Ascidian cannibalism correlates with larval behavior and adult distribution. J Exp Mar Biol Ecol 117:9-26

Zimmer RK, Butman CA (2000) Chemical signaling processes in the marine environment. Biol Bull 198:168-187

Zito-Livingston AN, Childress MJ (2009) Does conspecific density influence the settlement of Caribbean spiny lobster Panulirus argus postlarvae? N Z J Mar Freshw Res 43:313-325

Submitted: September 3, 2012; Accepted: October 24, 2013 Proofs received from author(s): February 3, 2014 